\title{
Hubungan Self EfficacyDengan Burnout Pada Guru Di Sekolah Dasar Inklusi
}

\section{Correlational Between Self-Efficacy And Burnout In Primary Inclusion Teacher}

\author{
Shalia Septianisa \& Riselligia Caninsti \\ Fakultas Psikologi, Universitas YARSI, Jakarta, 10510, Indonesia \\ Email: riselligia.caninsti@yarsi.ac.id
}

KATA KUNCI Sekolah Inklusi, Self- efficacy, Burnout, Anak Berkebutuhan Khusus

KEYWORDS Inclusion School, Self-efficacy, Burnout, Children with Dissabilities

ABSTRAK Meningkatnya jumlah Anak Berkebutuhan Khusus (ABK) yang belum bersekolah mendorong berdirinya sekolah inklusi sebagai salah satu inovasi pendidikan bagi penyandang cacat (disabilitas). Sekolah inklusi menerima $A B K$ dan menyediakan layanan pendidikan yang disesuaikan dengan kebutuhan Anak Tanpa Kebutuhan Khusus (ATBK) dan ABK, seperti penyesuaian kurikulum, pembelajaran, penilaian, dan sarana prasarananya. Adanya tugas tambahan terhadap guru sekolah inklusi dapat menyebabkan guru mengalami stres yang tinggi dan merasa tertekan saat meghadapi keanekaragaman karakter siswa, hal ini dapat menimbulkan burnout pada guru. Kondisi burnout yang dialami guru diasumsikan berhubungan dengan kondisi self efficacy. Self efficacy seseorang dapat mempengaruhi aktifitas, besarnya usaha yang dikeluarkan dan daya tahan dalam menghadapi rintangan. Penelitian ini bertujuan untuk melihat hubungan antara self efficacy dengan burnout pada guru di sekolah dasar inklusi. Diharapkan dengan diketahuinya burnout dan self efficacy, guru dapat menangani permasalahannya dan lebih profesional dalam menangani siswa berkebutuhan khusus. Penelitian dilakukan dengan penyebaran skala self efficacy dan skala burnout kepada 80 orang guru pada 12 sekolah inklusi di Jakarta Pusat dengan karateristik yang sudah ditentukan sebelumnya. Hasil penelitian menunjukkan nilai r yaitu -0,112 dan angka signifikansi 0,324 ( $p>0,05)$ yang berarti tidak terdapat hubungan yang signifikan antara self efficacy dengan burnout pada guru di sekolah dasar inklusi.

ABSTRACT The number of children with special needs who have not been attending school is increasing. The condition is encouraging the establishment of inclusive school as one of the innovation education for persons with disabilities. Inclusion school receiving children with disabilities and provide educational services adjusted with the needs of children without special needs, such as adjusting the curriculum, teaching, assessment, and infrastructure facilities. At inclusion school, the teacher can lead to stressed and feel depressed when faced the diversity character of children. The stressed condition can lead to the emergence of burnout. 
Researcher assummed that burnout can be correlated with self-efficacy. This study aimed to examine the correlation between self-efficacy and burnout in primary inclusive school's teachers. It is expected by knowing burnout (fatigue) and self-efficacy, teachers can solve the problem and more professional in dealing with disability students. The data collected by questionnaires, there are self-efficacy scale andburnout scale that given to 80 teachers in 12 schools in Central Jakarta inclusive school with predetermined characteristics. The result showed that the value of $r$ and the number of significance $0.324-0.112$ ( $p>0.05$ ), which means there is no significant correlation between self-efficacy and burnout in primary inclusive school's teachers.

\section{PENDAHULUAN}

Pada tahun 2012 tercatat 1.544 .184 jiwa jumlah anak berkebutuhan khusus di Indonesia.Jumlah ini mengalami peningkatan setiap tahunnya.Diantara anak berkebutuhan khusus ada yang tidak bersekolah dan belum mengeyam pendidikan. Anak berkebutuhan khusus yang bersekolah sekitar 330.764 anak (berusia 5-12 tahun), sementara 245.000 anak usia sekolah belum mengeyam pendidikan di sekolah (Data dalam surat kabar kompas, 2014). Hadirnya sekolah inklusi sebagai tempat pendidikan bagi anak berkebutuhan khusus membantu masyarakat dan pemerintah dalam mengurangi jumlah anak berkebutuhan khusus yang tidak bersekolah. Di Daerah Khusus Ibu Kota Jakarta (DKI) tercatat sebanyak 461 anak berkebutuhan khusus yang sudah terlayani pada pendidikan inklusi di Sekolah Dasar Negeri dan Sekolah Dasar Swasta (Mujito, 2013).

Sekolah inklusi adalah wadah penempatan anak berkelainan tingkat ringan, sedang dan berat secara penuh di kelas reguler (Staub dan Peck dalam Maujito, 2013).Di sekolah inklusi anak berkebutuhan khusus dapat berinteraksi langsung dengan anak yang normal.Anak berkebutuhan khusus juga di dampingi oleh guru pendamping khusus selain guru mata pelajaran.Sekolah inklusi secara tidak langsung juga bermanfaat bagi anak normal untuk dapat saling menghargai dan mengembangkan sikap empati antar satu dengan yang lain (Mujito, 2013).
Beberapa permasalahan yang muncul di sekolah inklusi, diantaranya: pertama, kurangnya tenaga pengajar atau guru sedangkan jumlah sekolah inklusi terus meningkat (Attami, 2013), sebagai contoh keterbatasan guru pembimbing khusus (GPK) di salah satu SD di daerah Jakarta Pusat, terdapat 21 murid berkebutuhan khusus, tapi hanya ada satu guru pembimbing (Harian Pelita dalam Mujito, 2013). Kedua, rendahnya kemampuan guru dalam membina anak di sekolah inklusi, hal dikarenakan guru belum mendapat bekal kompetensi yang memadai dalam mengajar anak berkebutuhan khusus (Direktorat PPK-LK Dikdas Kemendiknas dalam Mujito, 2013).Ketiga, masalah kesejahteraan guru yang masih belum di perhatikan (Sofa, 2008).

Keterangan di atas menunjukkan bahwa di sekolah inklusi permasalahan yang paling mendasar adalah faktor guru. Guru adalah pendidik profesional dengan tugas utama mendidik, mengajar,membimbing, mengarahkan, melatih, menilai, dan mengevaluasi peserta didik pada pendidikan anak usia dini, pendidikan formal, pendidikan dasar, dan pendidikan menengah. Guru pada sekolah inklusi berperan langsung dalam interaksi siswa, baik itu kepada siswa yang berkebutuhan khusus, maupun siswa non berkebutuhan khusus. Dalam menangani anak-anak berkebutuhan khusus, guru memerlukan pengetahuan tentang anakanak tersebut, keterampilan mengasuh dan melayaninya.Anak berkebutuhan khusus 
perlu mendapat dorongan, tuntunan, dan praktek langsung secara bertahap. Potensi yang dimiliki anak-anak berkebutuhan khusus akan tumbuh berkembang seiring dengan keberhasilan peran pendamping dalam memahami dan memupuk potensi anak-anak tersebut. Jika anak berkebutuhan khusus mendapatkan pelayanan yang tepat, khususnya keterampilan hidup (life skill) sesuai minat dan potensinya, maka anak akan lebih mandiri. Namun, jika tidak ditangani secara tepat, maka perkembangan kemampuan anak mengalami hambatan dan menjadi beban guru, keluarga, masyarakat dan negara.

Tugas-tugas guru di sekolah inklusi menjadi sebuah tantangan sekaligus beban bagi guru karena tidak semua guru pada sekolah inklusi mempunyai latar belakang sebagai guru pendamping khusus.Hal ini menyebabkan guru mengalami stres ketika menghadapi keanekaragaman karakter anak.Tingkat stres yang dialami guru sekolah inklusi memiliki intensitas lebih tinggi dibanding sekolah umum (Hans, 2011).Kondisi seperti inilah yang akhirnya dapat menjadi pemicu munculnya burnout (kelelahan kerja) pada guru, yang ditandai dengan kondisi lelah dan letih secara fisik dan psikologis, sehingga dapat mengganggu performa kerjanya.

Burnout pada guru (teacher burnout) adalah ketidakmampuan pengajar untuk bekerja dengan efektif sebagai akibat dari beban pekerjaan yang berlebihan dan stres (Freudenberger dalam Rafiah, 2010).Penjabaran lainnya mengenai teacher burnout diungkapkan oleh Carter (dalam Rafiah, 2010) yaitu kelelahan secara fisik, emosional dan sikap yang dimulai dengan perasaan tidak nyaman dan hilangnya kesenangan saat mengajar.

Guru yang mengalami burnout berpotensi menarik diri, tidak yakin dan merasa tidak mampu menyelesaikan tugastugasnya, melihat anak berkebutuhan pendidikan khusus di kelasnya sebagai beban tambahan atau masalah, bukan sebagai tantangan dan atau pengayaan (Rusdianti, 2011).Banyaknya beban kerja seorang guru dituntut untuk mempunyai keyakinan yang tinggi mengenai kemampuan dalam melakukan tugastugasnya, self efficacy merupakan penilaian diri, apakah dapat melakukan tindakan yang baik atau buruk, tepat atau salah.

Self efficacy adalah keyakinan seseorang akan kemampuan dirinya untuk melakukan suatu tindakan tertentu dalam situasi spesifik (Bandura, 1986). Keyakinan ini penting karena seringkali guru yang memiliki keterampilan yang berkaitan dengan suatu tugas tidak memiliki keyakinan terhadap keterampilan tersebut, sehingga tugas tersebut tidak dapat diselesaikan dengan baik.

Menurut Bandura (1986), self efficacy seseorang mempengaruhi aktifitas, besarnya usaha yang dikeluarkan dan daya tahan dalam mengahadapi rintangan atau pengalaman yang tidak menyenangkan serta pola pikir dan reaksi emosional. Semakin kuat self efficacy yang dimiliki seseorang, semakin terdorong untuk tetap bertahan pada aktivitas yang memiliki tantangan. Selain itu, individu juga akan semakin terpacu untuk menghadapi masalahmasalah yang ada dan akan mengeluarkan usaha untuk menguasai masalah yang dihadapinya tersebut. Demikian pula halnya dengan guru, semakin kuat self efficacy yang dimiliki guru maka akan semakin terdorong untuk tetap bertahan pada aktivitas walaupun banyak masalah yang harus dialami oleh mereka.

Self efficacy (keyakinan) termasuk kedalam salah satu aspek soft skill dalam Islam.Menurut Rahmayulis (2013) kekuatan keyakinan dapat menjadi pendorong utama pencapaian tujuan yang ditetapkan seseorang. Sebab, dengan keyakinan kita bersemangat dan menyerahkan apa yang telah kita upayakan kepada Allah, kita percaya dengan kemampuan yang dimiliki dapat membantu dalam mewujudkan mimpi kita. Hal tersebut terlihat dari hasil penelitian Maharani (2011) yang berjudul Hubungan Antara Self Efficacy Dengan Burnout Pada Guru Sekolah Dasar Negeri X Di Kota 
Bogor.Hasil penelitian ini menunjukkan semakin tinggi self efficacy yang dimiliki oleh guru SDN X semakin rendah burnout yang dialaminya, dan begitu pula sebaliknya. Berangkat dari penjelasan yang telah diuraikan di atas, maka yang menjadi permasalahan dalam penelitian ini adalah: Apakah terdapat hubungan antara self efficacy dengan burnout pada guru di Sekolah Dasar inklusi? Penelitian ini bertujuan untuk melihat hubungan antara self efficacy dengan burnout pada guru di Sekolah Dasar inklusi.

Teori self efficacyyang digunakan dalam penelitian ini didasarkan dari pendapat Bandura (dalam Feist and Feist, 2009) yaitu keyakinan seseorang dalam kemampuannya untuk melakukan suatu bentuk kontrol terhadap keberfungsian orang itu sendiri dan kejadian dalam lingkungan. Menurut Bandura (dalam Alwisol, 2004), ada empat faktor yang mempengaruhi self efficacy seseorang, yaitu:

\section{Pencapaian Hasil (Enactive Attainment)}

Pada faktor ini, jika individu pernah berhasil mencapai suatu prestasi tertentu, maka hal tersebut dapat meningkatkan penilaian akanself efficacy. Pengalaman keberhasilan juga dapat mengurangi kegagalan, khususnya jika pengalaman kegagalan tersebut timbul disaat awal terjadinya suatu peristiwa, dan kegagalan tersebut juga tidak akan mengurangi usaha yang sedang dilakukan individu dalam menghadapi dunia luar.

2. Pengalaman Orang Lain (Vicariuos Experience)

Pengalaman orang lain adalah sumber kedua dari self efficacy, sumber ini dapat diperoleh dari pengamatan terhadap pengalaman orang lain. Dengan melihat keberhasilan orang lain akan suatu tugas yang sama maka akan meningkatkan self efficacy individu sebagai pengamat. Dan dengan melihat pengalaman orang lain, maka individu tersebut akan cenderung merasa mampu melakukan hal yang sama apalagi didukung dengan kepercayan diri yang tinggi dan kemampuan yang dimiliki. Adapun pengamatan terhadap orang lain dipengaruhi beberapa faktor, yaitu karakteristik model, kesamaan antar individu dengan model, tingkat kesulitan tugas, keadaan situasional dan keanekaragaman hasil yang mampu dicapai oleh model.

3. Persuasi Verbal (Verbal Persuation)

Persuasi sosial adalah sumber ketiga yang dapat mempengaruhi self efficacy individu. Dampak dari sumber ini cukup terbatas, tetapi dalam kondisi yang tepat, persuasi dari orang lain dapat meningkatkan atau menurunkan self efficacy. Persuasi verbal dari sumber yang terpercaya mempunyai daya yang lebih efektif dibandingkan dari hal yang sama dari sumber yang tidak terpercaya.

4. Kondisi Fisiologis (Psychological State) Sumber terakhir yang dapat mempengaruhi self efficacy adalah kondisi fisiologis dan emosional individu (Bandura dalam Feist \& Feist 2009). Emosi yang kuat biasanya akan mengurangi performa; saat seseorang mengalami ketakutan yang kuat, kecemasaan akut, atau tingkat stres yang tinggi, kemungkinan akan mempunyai self efficacy yang rendah. Walaupun demikian, dalam beberapa kondisi, jika rangsangan emosional tidak terlalu intens, maka dapat diasosiasikan dengan peningkatan performa sehingga hanya kecemasaan normal yang terbentuk

Self-efficacy guru dapat diartikan sebagai penilaian guru tentang kemampuan atau kesanggupan dirinya untuk melaksanakan tugas-tugasnya sebagai seorang pendidik, pengajar, dan pembimbing siswa (Bandura,1997). Terdapat tujuh aspek teacherself efficacy menurut Bandura (1997), yaitu:

\section{Efficacy to Influence Decision making}

Keyakinan seorang guru memberi pengaruh seberapa besar dalam setiap pembuat keputusan yang dibuat oleh sekolah dan dalam mengutarakan 
pendapat atau pandangan tentang berbagai hal yang penting di sekolah.

2. Efficacy to Influence School Resources Keyakinan seorang guru untuk mendapatkan alat dan bahan pembelajaran yang dibutuhkan, mempengaruhi jumlah atau ukuran kelas di sekolah, keyakinan atau kemampuan untuk mempengaruhi siswa yang sulit, memajukan pembelajaran ketika siswa tidak mendapat dukungan dari rumah, untuk membuat siswa tetap pada tugas yang sulit, untuk meningkatklan ingatan siswa tentang materi yang diajarkan, untuk selalu memotivasi siswa, dan untuk menangulangi pengaruh buruk kondisi masyarakat pada belajar siswa.

\section{Instructional Self-Efficacy}

Keyakinan dalam mempengaruhi ukuran kelas, untuk mendekati siswa yang sulit, untuk memajukan pembelajaran ketika siswa yang diajar tidak mendapat dukungan dari rumah, untuk membuat siswa tetap pada tugas yang sulit, meningkatkan ingatan siswa terhadap pembelajran yang diajarkan sebelumnya, memotivasi siswa yang minat belajarnya rendah, untuk menangulangi pengaruh buruk kondisi masyarakat pada belajar siswa, dan membuat siswa tetap mengerjakan PR.

\section{Disciplinary Self-Efficacy}

Keyakinan kedisiplinan untuk membuat siswa tetap mematuhi aturan di dalam kelas, untuk mengendalikan perilaku yang menganggu di dalam kelas, dan mencegah perilaku bermasalah di dalam lingkungan sekolah.

5. Efficacy to Enlist Parental Involvement

Keyakinan dalam meminta keterlibatan orang tua pada kegiatan yang dilakukan oleh pihak sekolah, membantu orang tua dalam membantu anak mereka berbuat baik di sekolah, membuat orang tua merasa nyaman untuk datang ke sekolah.

\section{Efficacy to Enlist Community} Involvement

Keyakinan untuk mendapatkan keterlibatan masyarakat dalam bekerjasama dengan pihak sekolah, untuk mendapatkan ketersediaan atau keterlibatan lembaga keagamaan dengan pihak sekolah.

7. Efficacy to Create a Positive School Climate

Keyakinan untuk membuat sekolah menjadi tempat yang aman, membuat para peserta didik senang datang ke sekolah, membuat para peserta didik percaya dengan guru-gurunya, membantu guru-guru lain dengan kemamapuan mengajar seseorang, meningkatkan kerjasama antar guru dan tata usaha untuk membuat sekolah berjalan dengan efektif, untuk mengurangi angka putus sekolah, mengurangi ketidakhadiran di sekolah, membuat siswa percaya bahwa siswa dapat mengerjakan tugas sekolah dengan baik.

Istilah burnout pertama kali diperkenalkan oleh Herbert Freundenberger pada tahun 1974.Burnout adalah suatu kondisi kelelahan yang terjadi karena seseorang bekerja terlalu intens tanpa memperhatikan kebutuhan-kebutuhan pribadinya (Freudenberger dalam Farber,1991). Burnout merupakan kondisi emosional dimana seseorang merasa lelah dan jenuh secara mental ataupun fisik sebagai akibat tuntutan pekerjaan yang meningkat (Maslach, Schaufeli, dan Leiter, 2001).

Baron dan Paulus (dalam Rostiana, 2004) mendifinisikan burnout sebagai sindrom kelelahan fisik, emosional, dan kelelahan mental, dan juga ditunjang perasaan rendah diri serta diiringi dengan stres yang intens dan berkepanjangan. Burnout merupakan penarikan diri secara psikologis terhadap pekerjaan akibat adanya stres atau ketidakpuasaan yang berlebihan (Cherniss dalam Crandall, 1995).Individu yang mengalami burnout biasanya melakukan perubahan perilaku dan sikap dalam bentuk reaksi menarik diri secara psikologis dari pekerjaannya, seperti membolos, sering terlambat, bersikap sinis terhadap siswa, menjaga jarak dengan 
siswa, dan keinginan kuat untuk pindah pekerjaan.

Menurut Maslach dkk (2001) terdapat dua faktor yang mempengaruhi burnout, yaitu faktor situasional yang terdiri dari beban kerja, kontrol, reward, komunitas, keadilan, dan nilai-nilai berhubungan dengan burnout. Di samping faktor situasional, faktor individual yang berupa faktor demografis (usia, jenis kelamin, status pernikahan) juga berpengaruh terhadap burnout .

Maslach, Schaufeli, dan Leiter (2001) mengemukakan bahwa burnout mempunyai tiga dimensi, yaitu:

\section{Exhaustion (Kelelahan)}

Kelelahan adalah yang paling banyak dilaporkan dan paling dianalisis dari ketiga aspek burnout.Hal ini ditandai dengan kelelahan fisik yang terjadi berkepanjangan (sakit kepala, flu, insomnia dan lain-lain), kelelahan mental (merasa tidak bahagia, merasa tidak berharga, merasa gagal dan lainlain), dan kelelahan emosional (sedih, bosan, tertekan dan lain-lain). Sehingga saat seseorang mengalami burnout maka mereka akan merasa energi mereka terkuras dan perasaan 'kosong' yang tidak dapat diatasi.

2. Cynisim (Depersonalisasi)

Depersonalisasi merupakan upaya untuk membuat jarak antara diri sendiri dengan orang lain, secara aktif mengabaikan kualitas yang membuat mereka unik dan menarik orang. Adanya proses penyimpangan antara tuntutan pekerjaan dan kemampuan individu. Perilaku tersebut merupakan upaya untuk melindungi diri dari perasaan kecewa, karena dengan berperilaku demikian mereka dapat terbebas dari tuntutan pekerjaannya.

3. Low personal accomplisment (Rendahnya hasrat pencapaian prestasi diri)

Pada dimensi ketiga ini ditandai dengan perasaan tidak puas terhadap diri sendiri dan pekerjaan. Dalam hal ini mereka belum melakukan hal-hal yang bermanfaat dalam kehidupan, sehingga memicu penilaian rendah akan kompetensi diri dan pencapaian keberhasilan diri. Perasaan tidak berdaya dan tidak mampu lagi melakukan tugastugas yang dibebankan terlalu berlebihan sehingga berimbas pada penolakan akan tugas yang baru.

Berdasarkan modifikasi Edelwich dan Brodsky's model (dalam Farber, 1991), burnout pada guru terjadi melalui beberapa tahap yaitu:

1. Antusiasme dan dedikasi

Tahap ini terjadi pada masa awal kerja. Seorang guru memulai pekerjaannya dengan penuh semangat dengan harapan bahwa pekerjaan yang mereka lakukan akan dapat berarti bagi masyarakat dan memberikan kepuasan yang besar pada semua orang.

2. Frustasi dan marah

Pada tahap ini guru mulai merasakan berbagai masalah dan kesulitan yang muncul dalam menjalankan pekerjaannya.Lingkungan kerja yang kurang kooperatif (seperti kelas yang kacau, siswa yang tidak peduli, orang tua murid yang semakin menuntut, administrator yang kurang peka dan pihak sekolah yang kurang mendukung) menimbulkan perasaan frustasi, kehabisan energi, sehingga guru menjadi lebih mudah marah pada siswa.

3. Perasaan tidak berarti

Pada tahap ini guru berfikir bahwa terjadi ketidakseimbangan antara usahanya yang telah dilakukan dengan imbalan yang diperoleh.Sehingga dengan ketidakseimbangan ini, guru merasakan yang telah dikerjakan selama ini tidak berarti.

4. Menurunnya komitmen guru terhadap pekerjaan

Pada tahap ini semangat serta harapan guru yang ada pada saat awal bekerja mulai mengalami penurunan. Dalam proses belajar mengajar guru tidak lagi peduli dengan kebutuhan siswa, yang terpenting bagi guru adalah mereka telah menjalankan tugasnya. 
5. Rentan terhadap gangguan fisik, kognitif dan emosi

Pada tahap ini guru mulai mengalami gangguan fisik seperti sakit kepala, sakit punggung, sakit perut dan gangguan emosi seperti merasa kesal, meningkatnya absen (ketidakhadiran guru), muncul pemikiran untuk berhenti dari pekerjaannya, dan tidak tahan untuk menghabiskan waktu dalam kelas.

6. Perasaan kekosongan dan hilangnya kepedulian

Merupakan tahap akhir dari burnout yang dialami guru.Pada tahap ini, guru menilai pekerjaannya sebagai pekerjaan yang tidak berarti dan hanya gaji yang memotivasi mereka untuk tetap bekerja.Stainback dan Stainback (1996) mengemukakan definisi dari sekolah inklusi yaitu "the practice of including every oneirrespective of talent, disability, sosioeconomic background, or cultural origin-in supportive mainstream schools and classrooms where all student needs are met". Dengan kata lain sekolah inklusi merupakan sekolah yang mana semua kebutuhan siswa dapat dipenuhi. Sekolah menampung siswa di kelas yang sama tanpa memandang bakat, ketidakmampuan, latar belakang ekonomi dan suku bangsa.

Mujito (2013) menyampaikan tiga jenis guru dalam sekolah inklusi, yaitu guru kelas, guru mata pelajaran dan guru pendidikan khusus. Guru kelas berfungsi sebagai pengajar atau pendidik di sekolah reguler yang menyelenggarakan pendidikan inklusi dan mengajar di kelas dengan siswa kebutuhan khusus. Guru kelas harus dapat menguasai kurikulum sekolah, strategi pembelajaran pendidikan inklusi dan mampu bekerja dalam tim. Guru mata pelajaran berfungsi sebagai pengajar yang mengajar pada mata pelajaran tertentu sesuai dengan kualifikasi yang dipersyaratkan.

\section{METODE PENELITIAN}

Penelitian ini menggunakan pendekatan kuantitatif dengan jenis penelitian korelasional.Menurut Sugiyono
(2010) penelitian kuantitatif adalah penelitian yang datanya berbentuk angka dan analisa menggunakan statistik.Hipotesis penelitian ini adalah adanya hubungan antara self efficacy dengan burnout pada guru di sekolah dasar inklusi.Sampel dalam penelitian ini adalah guru di sekolah dasar inklusi Jakarta Pusat. Adapun karakteristik dari sampel penelitian adalah :

1. Guru yang masih aktif bertugas disekolah inklusi

2. Guru yang pernah berinteraksi atau mengajar anak inklusi

3. Minimal pendidikan D3

Alat ukur self efficacy mengacu pada Bandura's Isntrument Teacher Self Efficacy Scale yang dikembangkan oleh Bandura.Selanjutnya peneliti melakukan modifikasi beberapa item pada alat ukut tersebut yang disesuaikan berdasarkan situasi pada sekolah inklusi.

Bandura telah membuat 30 item dengan tujuh subskala, yaitu: efficacy to influence decision making, efficacy to influence school resources, instructional self-efficacy, disciplinary self-efficacy, efficacy to enlist parental involvement, efficacy to enlist community involvement, efficacy to create a positive school climate. Semakin tinggi nilai dalam skala teacherself efficacy maka semakin tinggi pula tingkat self efficacy, sebaliknya jika semakin rendah nilai dalam skala teacher self efficacy maka semakin rendah pula tingkat selfefficacy.

Pada penelitian ini, peneliti menggunakan uji validitas konstruk (construct validity), yaitu dengan melihat kesesuaian antara hasil alat ukur dengan kemampuan yang ingin diukur.Dalam penelitian ini digunakan teknik perhitungan yaitu korelasi product moment. Adapun rumusnya adalah $\mathrm{r}=\mathrm{N}-2$, dengan keterangan jika $r$ hitung lebih besar dari $r$ tabel maka artinya variabel valid, sebaliknya jika $r$ hitung lebih kecil dari $r$ tabel maka artinya variabel tidak valid (Sugiyono, 2010).Uji variable konstruk 
dapat digunakan dengan carajudgment experts atau pendapat para ahli. Setelah dilakukan penilaian oleh para ahli maka dilanjutkan dengan uji coba instrumen.Hasil uji coba alat ukur juga dapat digunakan sebagai pengumpulan data bagi peneliti (try out terpakai), hanya saja ada penambahan satu indikator.

Pengujian reliabilitas dalam penelitian ini, menggunakan metode internal consistency yaitu dengan cara mencobakan instrument sekali saja, kemudian data yang diperoleh dianalisis berdasarkan teknik tertentu.Peneliti menggunakan teknik Cronbach'sAlfa dalam menghitung reliabilitas, melalui hasil perhitungan menggunakan SPSS for Windows 21.0. Nilai koefisien reliabilitas dengan metode konsistensi internal dalam suatu tes setidaknya mencapai 0,80 (Kaplan, 2005).

Berdasarkan uji psikometri alat ukur, didapatkan hasil reliabilitas pada skala self efficacy dengan $\alpha=0,943$. Hasil analisis item menunjukkan bahwa nilai corrected item total correlation yaitu $\mathrm{r}_{\text {hitung }}>0,2199$ dapat digunakan dalam alat ukur untuk pengambilan data, sedangkan nilai corrected item total correlation yang $\mathrm{r}_{\text {hitung }}<0,2199$ tidak dapat digunakan dan harus dieliminasi (Sugiyono, 2010).Pada hasil uji validitas skala self efficacy dari 31 item yang dibuat, tidak terdapat item yang gugur.

Alat ukur pada penelitian ini mengacu pada Maslach Burnout Inventory (MBI) yang dikembangkan oleh Maslach.Alat ini merupakan adaptasi dari MBI yang sudah digunakan oleh Ningdyah pada tahun 1999 dalam penelitiannya yang berjudul "Peranan Dimensi-Dimensi Birokrasi terhadap Burnout Perawat Rumah Sakit di Jakarta".Selanjutnya, peneliti melakukan modifikasi alat ukur yang digunakan oleh Lestari (2009) dalam penelitiannya yang berjudul "Analisis Kebutuhan Untuk Pengembangan Pelatihan Pencegahan Burnout pada Guru Tingkat SMU'. Adapun terdapat 13 item yang peneliti modifikasi berdasarkan situasi pada sekolah inklusi

Pengukuran reliabilitas setelah dilakukan uji psikometri ulang oleh peneliti didapatkan $\alpha=0,836$. Peneliti juga melakukan konsultasi pada ahli atau expert judgement.Pada uji validitas item, didapatkan skorcorrected item total corelation setiap item lebih dari 0,2199.Pada uji validitas skala burnout, dari 25 item yang telah di modifikasi terdapat 10 item yang gugur (di bawah 0,2199). Hasilnya tersisa 15 item yang digunakan dalam pengolahan data penelitian.

\section{ANALISIS \& HASIL}

Metode analisis untuk melakukan pengujian terhadap hipotesis asosiatif dengan dua variabel adalah Pearson Product Moment (Sugiyono, 2010). Berdasarkan perhitungan korelasi antara variabel self efficacy dan burnout diperoleh hasil sebagai berikut:

\section{Tabel 1. Hubungan Antara Self Efficacy dengan Burnout Pada Guru di Sekolah Dasar Inklusi}

\begin{tabular}{llc}
\hline & & Self-efficacy \\
\hline Burnout & Pearson &,- 112 \\
& Correlation & \\
& Sig. (2-tailed) &, 324 \\
& Sum of Squares & $-2459,313$ \\
& and & \\
& Cross-products & \\
& Covariance & $-31,131$ \\
& N & 80 \\
\hline Hasil & analisis data di atas
\end{tabular}

menunjukkan bahwa "Hubungan Antara Self efficacy dan Burnout Pada Guru di Sekolah Dasar Inklusi" memiliki nilai koefisien korelasi $r=-0,112$. Nilai tersebut dapat diartikan bahwa hubungan antara self efficacy dengan burnout sangat rendah. Berdasarkan nilai koefisien korelasi tersebut, dapat diketahui juga nilai koefisien deteminasi (koefisien penentu) yaitu sebesar $1,25 \%$, yang berarti hubungan erat antara self efficacy dengan burnout yang terjadi pada 80 orang sebesar 1,25\%, dan sebesar $98,75 \%$ hubungan antara self efficacy dengan burnout tersebut ditentukan 
oleh faktor-faktor lain (Sugiyono, 2010).Hal ini dapat di artikan bahwa tinggi atau rendahnya self efficacy tidak menentukan tinggi atau rendahnya burnout pada guru sekolah dasar inklusi di Jakarta Pusat.

\section{DISKUSI}

Hasil penelitian ini tidak memiliki sesuaian dengan penelitian sebelumnya oleh Maharani (2011), yaitu terdapat hubungan negatif antara self efficacy dengan burnout pada guru.Terdapat perbedaan antara hasil penelitian Maharani (2011) dengan penelitian ini, yaitu pada sekolah yang menjadi target peneliti memiliki sistem pendidikan inklusi (sekolah inklusi).Sekolah inklusi adalah sekolah regular (biasa) yang menerima anak berkebutuhan khusus (ABK) dan menyediakan sistem layanan pendidikan yang disesuaikan dengan kebutuhan anak tanpa kebutuhan khusus (ATBK) dan ABK melalui adaptasi kurikulum, pembelajaran, penilaian, dan sarana prasarananya (Danim, 2002).

Pada penelitian Skaalvik (2010) komponen autonomy (strategi pendidikan, kurikulum nasional yang di tetapkan, metode pengajaran) dalam school context pada guru lebih dapat memprediksi hubungan antara self efficacy dengan burnout. School context pada sekolah inklusi dapat dilihat pada sistem pembelajaran dikelas dimana guru reguler mengajar anak berkebutuhan khusus dalam satu kelas yang sama dengan anak normal dengan kurikulum yang sama. Selain itu adanya guru pendamping khusus yang berwenang dalam menyusun program pengajaran atau praktik (identifikasi, asesmen, menyusun program khusus) bersama kepala sekolah dan guru reguler, serta terdapat program IEP (Individualized Education Program) bagi anak berkebutuhan khusus.

Dilihat dari usianya, tidak ada perbedaan tingkat burnout pada guru yang memiliki rentang usia antara 18-39 tahun dengan guru yang berusia antara $40-60$ tahun. Dari 80 orang subjek penelitian, 3 guru yang memiliki tingkat burnout sangat rendah berusia 30 tahun (1 orang) dan 50 tahun (2 orang). Sementara guru yang memiliki tingkat burnout sangat tinggi juga berjumlah 3 orang dengan usia 30 tahun (1 orang) dan 50 tahun (2 orang).

Berdasarkan jenis kelamin tidak ada perbedaan tingkatan burnout pada guru yang memiliki jenis kelamin perempuan dan guru yang memiliki jenis kelamin lakilaki. Dari 80 orang subjek penelitian, 22 guru memiliki tingkat burnout rendah, dengan rincian guru yang berjenis kelamin laki-laki 6 orang dan berjenis kelamin perempuan 16 orang. Sementara guru yang memiliki tingkat burnout tinggi berjumlah 20 orang, dengan jenis kelamin laki-laki 8 orang dan jenis kelamin perempuan 12 orang.

Dilihat berdasarkan masa kerja, tidak ada perbedaan tingkatan burnout pada guru yang memiliki masa kerja 1-4 tahun, 5-19 tahun dan >20 tahun.Dari 80 orang subjek penelitian, 32 guru yang memiliki tingkat burnout sedang dengan masa kerja 1-4 tahun (4 orang), 5-19 tahun (9 orang) dan >20 tahun (19 orang).Sementara guru yang memiliki tingkat burnout tinggi berjumlah 22 orang dengan masa kerja 1-4 tahun (3 orang), 5-19 tahun (14 orang), >20 tahun (5 orang).

Penjelasan mengenai tingkatan burnout berdasarkan usia, jenis kelamin dan masa kerja di atas dapat diperkuat dengan penelitian Dewi (2013) yang menyebutkan bahwa tidak ada perbedaan usia, jenis kelamin dan masa kerja dengan tingkatan burnout pada guru sekolah dasar inklusi.

Berdasarkan status, dari 80 guru terdapat guru yang memiliki burnout rendah berstatus menikah (21 orang) dan belum menikah (1 orang). Sementara itu, guru yang memiliki burnout tinggi memiliki status menikah sebanyak 20 orang. Menurut Caputo (1991), profesional yang berstatus lajang (belum menikah) lebih banyak mengalami burnout daripada yang telah menikah. Hal ini tidak sejalan dengan hasil penelitian karena sebagian besar subjek 
berstatus menikah pada penelitian ini berjenis kelamin wanita.Penjelasan diatas dapat di perkuat dengan teori yang di kemukan oleh Anoraga (2005), yaitu wanita yang telah menikah mempunyai beban dan hambatan lebih berat dibanding wanita yang belum menikah.Dalam arti, wanita harus lebih dahulu mengatasi urusan keluarga-suami, anak dan hal-hal lain yang menyangkut domestik rumah tangganya.

Oleh karena itu pada tingkat burnout sangat rendah, rendah, sedang, tinggi dan sangat tinggi terdapat subjek dengan usia, jenis kelamin dan masa kerja yang tidak spesifik. Menurut Pines (dalam Fiber, 1991) tingkat kelelahan fisik dalam kuisioner burnout, guru merasa untuk melayani anak berkebutuhan khusus dapat menghabisakan energi setiap harinya akan tetapi masih dapat teratasi karena hanya 3 orang yang memiliki burnout sangat tinggi. Terdapat 3 orang yang memiliki burnout sangat rendah pada kelalahan mental dan emosional dapat dikatakan guru masih dapat peduli dengan anak berkebutuhan khusus dan dapat mengatur masalah emosi dengan tenang kepada siswa berkebutuhan khusus walaupun masih ada juga yang tidak peduli dan dan belum dapat mengatur permasalah emosi dengan tenang.

Berdasarkan pada usia, tidak ada perbedaan tingkatan self efficacy pada guru yang berusia 18-39 tahun dan 40-60 tahun. Dari 80 subjek penelitian 4 orang memiliki tingkat self efficacy sangat rendah berusia 30 tahun (1 orang) dan 50 tahun (3 orang).Sementara 9 guru yang memiliki tingkat self efficacy sangat tinggi berusia 20 tahun (1 orang), 30 tahun (1 orang), 40 tahun ( 3 orang) dan 50 tahun (4 orang).

Berdasarkan pada jenis kelamin tidak ada perbedaan tingkatan self efficacy pada jenis kelamin laki-laki dan jenis kelamin perempuan.Dari 80 subjek penelitian, 25 guru memiliki tingkat self efficacy rendah, dengan rincian guru berjenis kelamin lakilaki 5 orang dan perempuan 20 orang.Sementara itu, 18 guru yang memiliki self efficacy tinggi terdiri dari 3 orang lakilaki dan 15 perempuan.
Berdasarkan masa kerja, dari 80 subjek penelitian, 25 guru memiliki self efficacy rendah dengan masa kerja 1-4 tahun (2 orang), 5-19 tahun (11 orang) dan $>20$ tahun (12 orang). Sementara 18 guru memiliki tingkat self efficacy tinggi dengan masa kerja 1-4 tahun (2 orang), 5-19 tahun (10 orang) dan $>20$ tahun (8 orang).

Penjelasan mengenai tingkatan self efficacy berdasarkan usia, jenis kelamin dan masa kerja di atas dapat diperkuat dengan penelitian Andiny (2008) yang menyebutkan bahwa tidak ada perbedaan tingkatan self efficacy pada guru jika ditinjau berdasarkan usia, jenis kelamin dan masa kerjanya.

\begin{tabular}{ccc}
\multicolumn{2}{c}{ Bandura (1986) mengatakan bahwa } \\
sumber terpenting yang dapat
\end{tabular} mempengaruhi self efficacy adalah anactive attaiment (pencapaian hasil). Dimana jika individu pernah berhasil dalam mencapai suatu prestasi tertentu, maka hal tersebut dapat meningkatkan penilaian akan self efficacy. Jumlah guru yang memiliki self efficacy rendah dengan masa kerja $>20$ tahun lebih banyak daripada yang memiliki masa kerja <20 tahun, hal ini dikarenakan kurangnya pengalaman-pengalaman langsung yang dialami oleh guru pada konteks sekolah inklusi, selain itu jumlah anak berkebutuhan khusus yang bersekolah di sekolah inklusi juga masih tergolong sedikit.

\section{SIMPULAN}

Berdasarkan hasil penelitian yang telah dilakukan terhadap sampel subjek yang merupakan guru yang bekerja pada sekolah dasar inklusi di Jakarta Pusat, dengan menggunakan analisa data Pearson Product Moment diperoleh hasil signifikasi sebesar 0.324 dengan nilai skor koefisien korelasi sebesar $\mathrm{r}=-0,112$. Nilai skor koefisien korelasi tersebut menunjukkan tidak terdapat hubungan antara self efficacy dengan burnout pada guru di sekolah dasar inklusi, sehingga hipotesis alternative pada penelitian ini ditolak.

Sebanyak 25 orang guru $(31,25 \%)$ dari 80 subjek penelitian, memiliki tingkat 
self efficacy yang berada pada kategori rendah, dan 32 orang guru (40\%) memiliki kondisi burnout yang berada pada kategori sedang.

\section{SARAN}

Saran Praktis

a. Penelitian selanjutnya agar memperhatikan tingkat kesalahan dalam pengambilan sampel, dengan cara mengetahui jumlah sampel secara keseluruhan agar dapat menentukan taraf kesalahan dalam penelitian

b. Penelitian selanjutnya dapat memperhitungan faktor lain yang menentukan hubungan antar variabel self efficacy dan burnout pada guru, seperti faktor lingkungan sekolah (school context)

c. Peneliti selanjutnya dapat menambah data kontrol untuk variabel self efficacy, yaitu intensitas berinteraksi dengan anak berkebutuhan khusus agar dapat menambah pengalaman langsung untuk meningkatkan self efficacy pada guru.

Saran Metodologis

a. Melaksanakan pelatihan khusus bagi guru-guru yang latar belakang pendidikannya sebagai guru pendamping khusus, guna meningkatkan self efficacy atau tingkat keyakinan guru sekolah dasar inklusi di Jakarta Pusat.

b. Menambah jumlah guru pendamping khusus pada masing-masing sekolah dasar inklusi di Jakarta Pusat, guna mencegah atau mengurangi tingkat burnout pada guru.

\section{DAFTAR PUSTAKA}

Andiny, L. (2008). Perbedaan self efficacy antara guru SMA 'plus' dengan guru SMA 'non plus'.lib.ui.ac.id. Diakses 29 Agustus 2014.

Attami, M. (2013).Jumlah guru sekolah inklusi DIY belum memadai. http://www.antarayogya.com. Diakses 8 Desember 2013.
Bandura, A. (1986). Social foundations of thought and action: A social cognitive theory. Englewood Cliffs, NJ: Prentice Hall.

Bandura, A. (2006). Guide for constructing self efficacy scale. www.uky.edu. Diakses 15 Mei 2014.

Chrandall, $\mathrm{R}$ \& Pamela R. P. (1995).Occupational stres.United State of America: British Library.

Danim, S. 2002. Inovasi pendidikan dalam upaya peningkatan profesionalisme tenaga kependidikan. Bandung: Pustaka Setia

Dewi, S L. (2013). Tingkat burnout ditinjau dari karakteristik demografi (Usia, Jenis Kelamin, Masa Kerja) Guru SDN Inklusi di Surabaya. http://www.journal.unair.ac.id. Diakses 29 Mei 2014.

Farber, B. A, (1991). Crisis in education : Stress and burnout in the american teacher. Jossey-Bass Publishers, San Fransisco.

Feist J\& Feist J.G. (2009). Teori kperibadian edisi 7. Jakarta: Salemba Humanika.

Hans. (2011). Pendidikan sekolah inklusi ; Guru dan Siswa Belum Seimbang. http://www.pendis.kemenag.go.id.

Diakses 8 Desember 2013.

Kaplan, R. M., \& Saccuzzo, D. P. (2005). Psychological testing: Principles, applications, and issues. USA: Wadsworth.

Maharani, D R. (2011). Hubungan self Efficacy dengan burnout pada guru di sekolah dasar negeri $\mathrm{X}$ di kota Bogor. http://www.papers.gunadarma.ac.id.

Diakses 20 Oktober 2013

Maslach.,C\& Michael P. L. (1997). The thurt about burnout : How Organizations cause personal stress and what to do about it. San Fransisco : Bass Publishers

Maslach, C., Schaufeli, W.B., \& Leiter, M.P. (2001).Job burnout.Annual Review of Psychology. 
Mujito, Harizal, \& Elfindri.(2013). Pendidikan inklusif. Jakarta: Baduose Media.

Rafiah, D. 2010. Hubungan self efficacy dengan burnout pada guru sekolah luar biasa.Artikel. Jakarta: Fakultas Psikologi Universitas Islam Negeri Syarif Hidayatullah. Diakses 8 Desember 2013.

Ramayulis.(2013). Profesi dan etika keguruan. Jakarta: Kalam Mulia.

Rusdianti, S Dra.Potret sekolah inklusi di Indonesia. http://staff.uny.ac.id. Diakses 13 Oktober 2013.

Rostiana, D. N. (2004).Kejenuhan kerja (burnout) pada karyawan. Phronesis Universitas Tarumanagar.
Skaalvik, E. M., Skaalvik, S. (2009). Teacher self efficacy and teacher burnout: A study of relations. Journal. Norway: Norwegian University of Science and Technology, 7491 Trondheim

Stainback, W dan Stainback, S. (1996). Inclusion, a guide for educators. Maryland: Paul H. Brookes Publishing Co., Inc.

Sofa.(2008). Permasalahan guru yang dihadapi di Indonesia.Artikel. http://massofa.wordpress.com. Diakses tanggal 20 Oktober 2013.

Sugiyono, Prof., Dr. (2010). Statistika untuk penelitian. Bandung: Alfabeta 